\title{
Chinese Telecom Companies Foray Into Africa
}

\author{
By Dr Daouda Cissé \\ Centre for Chinese Studies, Stellenbosch University
}

\begin{abstract}
China's Outward Foreign Direct Investment (OFDI) to Africa has been driven by its quest for natural resources not only to secure resources for itself but also ensure its modernisation and urbanisation (Shenkar and Luo, 2004). Like the traditional Chinese investments' sectors in Africa (infrastructure, mining, oil; etc.), the telecommunication sector also fits into China's central government policy rationale to boost Chinese companies ventures abroad. Beyond this, investments in the telecommunication sector illustrate a broader case of qualitative changes in China's African investments. Chinese investment's pattern in Africa is shifting slightly from an exclusive engagement in extractive industries to an increasing inclusion of services (finance, banking and telecommunication) and manufacturing.
\end{abstract}

The boom of Africa's telecom industry, which is today one of the world's fastest growing, the liberalisation of the telecoms sector in many African countries and the willingness of their respective governments to improve the telecom environment have attracted more foreign investors. Chinese telecom companies' venture into Africa follows Beijing's "go out" strategy that wishes to see Chinese companies (StateOwned Enterprises (SOEs) at the central or provincial level as well as private companies) operating overseas. Chinese telecommunication companies' presence in the world market has been favoured by Beijing's policies for its companies to enter new markets, to acquire foreign technology and reinforce China's space and satellite programme (Executive Research Associates, 2009).

The paper explores the political economy of Chinese companies with more focus on telecommunication companies. It looks at the globalisation of Chinese companies, the Chinese telecommunication companies' - mainly ZTE and Huawei - "go out" strategy and their presence in Africa.

\section{Chinese telecommunication companies' presence in the world market has been favoured by Beijing's policies. \\ II}

\section{Globalisation of Chinese companies}

Through their internationalization, Chinese companies are building high profiles in overseas markets. Most scholars looking at the motivations of Chinese enterprises to go international agree that classical motivations play a key role in Chinese companies' investments abroad. Chinese multinational companies are to various extents resource-seeking, market-seeking and strategic asset-seeking (Buckley et al., 2007). Over the last years, China's economic growth has mainly relied on its export-driven policy which has focused on the search for new markets to sell Chinese manufacturing products to the world's market. The logical consequence of such policy is market-seeking motivations.

The poor availability of resources within China contrasts with the country's need for modernisation and resources. Chinese companies have thus developed activities in 
resource-seeking foreign direct investment (FDI) and basically implement them according to the targeted country or region. African and Central Asian countries are the main recipients of China's OFDI in natural resources such as oil, copper, coal. Due to the strategic importance of OFDI, a large number of Chinese multinational companies overseas are SOEs. But in recent years the fierce competition that prevails in China doubled with the rise of labour and production costs has driven many private Chinese companies to relocate overseas. According to Jing Gu (2009), strategic asset motivations play a key role for Chinese investors abroad. Compared to Western multinational investing abroad, these aspects (resource-seeking, market-seeking and strategic-asset seeking) give different characteristics to Chinese multinational corporations (MNCs). Besides, Chinese companies' operations abroad are supported by the Chinese government, be it at the central or provincial level. Such political, financial and diplomatic support gives Chinese MNC's a unique particularity in the global market and may arguably put them in a better position than non-Chinese companies. Chinese SOEs are supported by the government through financial aid and political influence to "catch up" with their relative late-coming to the international market (Alden and Davies, 2006). Competition in China's large and complex market is not only the key push factor for Chinese MNC to go overseas. The "go out" strategy undertaken by Beijing's central government in the late 1990s has contributed a lot to China's OFDI.

\section{1 \\ Chinese SOEs are supported by the government through financial aid and political influence to "catch up" with their relative late-coming to the international market.}

\section{The 'go out' strategy - not least including telecommunication enterprises}

During these last few decades, China's telecoms sector has experienced an unprecedented growth. Thus, following China's economic rise which was accompanied by the competitiveness of Chinese companies in global markets, a number of Chinese telecom firms have rapidly expanded their activities overseas to compete with foreign multinationals such as Ericsson, Alcatel, Nokia; etc. Beebe et al. (2006) argue that Chinese companies' motivations to go global are: to search for new markets to export their products, to acquire advanced management and technology skills and to secure China's natural resources. Chinese companies' foray into the international market is motivated by the search for new markets for growth.

Backed by their government and benefiting a high profit potential due to their price competitiveness, Chinese telecom companies ease competition by going global. However, to be internationally competitive, Chinese telecom MNCs need to learn foreign management styles and technology and build innovative brands. Innovation remains essential for Chinese companies to be accepted abroad and survive the global market's competition. Therefore building global brands is one of the centrepieces of China's $12^{\text {th }}$ five-year plan, while focusing on research and development are Chinese telecom companies' challenges and eyeing new trends on international markets. In fact, even if a large number of Chinese companies pave their way into overseas markets by developing and improving their management and technological abilities in order to improve their competitiveness, others build strong relationships with foreign enterprises and acquire foreign businesses via mergers and acquisitions (Beebe et al., 2006; Bonaglia et al., 2007; Salidjanova, 2011). 
The Chinese government's role in supporting its companies going overseas through the "go out" policy is visible and constitutes an important aspect in the internationalisation process of Chinese telecommunication companies. Through its agencies, organisations and financial institutions (China Exim Bank, China Development Bank and China Africa Development Fund) the Chinese government brings important support to Chinese companies overseas (Beebe et al., 2006). The Ministry of Commerce (MOFCOM), the National Development and Reform Commission (NDRC) and the State Administration of Foreign Exchange (SAFE) have all developed strategies and policies to assist Chinese companies going abroad. According to Xinhua (2006), Chinese premier Wen Jiabao reaffirmed the Chinese government's commitment to encourage globalisation by offering various types of support and including new policies and services to coordinate overseas investments and manage the risks. Preferential loans and buyer credit are thus provided to Chinese telecom companies operating abroad. For instance, in 2009, China Development Bank proclaimed, through a five-year cooperation framework agreement, it would provide ZTE with a US\$ 15 billion credit line including ZTE's overseas projects financing and credit limits (Brown, 2009).

As Chinese telecom companies wanted to go global and expand their business over China's borders, their global ambition was not a secret. During the past decade, Huawei established its research and development (R\&D) centres abroad. Li Cheng (2006) states that Huawei and ZTE are globalising faster and are determined to stay the course. Chinese companies' presence in the global telecom industry is changing the trend in this sector by creating competition and reshaping management strategies. Their participation in overseas market has taken different forms including R\&D, joint ventures, project contracting, M\&A, telecoms management and operation.

\section{As Chinese telecom companies wanted to go global and expand their business over China's borders, their global ambition was not a secret.}

\section{Chinese telecommunication companies in Africa}

Africa, an important and thriving market for telecom industry, plays a key role in Chinese telecom companies' activities across the continent, allowing them to gain partnership and collaboration among local telecom operators. The telecom sector in Africa has experienced important growth during recent years and has attracted an increasing number of investors. The willingness of African governments to modernise and develop their telecoms industry, telecom policies' liberalisation in some African countries in the 1990s and in early 2000 have made the African telecom environment favourable to foreign investors (Berg and Hamilton, 2001). For Chinese telecom companies (ZTE and Huawei), the lack of network coverage, the high costs of establishing landline networks across vast and often sparsely populated territory are among others the main motives to tap into Africa.

China's increasing presence in Africa's telecommunication sector is part of a multidimensional engagement in the continent to serve its broader strategy to enhance its global standing, counter western influence and to obtain resources and new export markets to feed its rapid economic expansion (Executive Research Associates, 2009). Beside construction, as well as mining and energy, telecommunication represents a 
key investment sector for China and participates to the Chinese economic development policy (Executive Research Associates, 2009). Investments in telecommunication goes hand in hand with the strategic policies of China's interests abroad to find new markets to export its manufacturing products, develop its technology and acquire foreign expertise. With its strategic political considerations, the primary objective of China is to see Chinese international competitive enterprises (Dumbaugh, 2008).

\section{Aggressive market mechanisms in Africa}

The two largest Chinese telecom companies (ZTE and Huawei) play an important role in the expansion of Chinese investments abroad and in China's political economy strategy overseas. Focused on the great and growing demand in mobile phone business in Africa, Chinese multinational telecom companies operate in the continent and are changing the telecom industry hierarchy by putting pressure on their main competitors in this area with their low cost mobile handsets and telecom equipment. According to Raushan Sagalbayeva (2011): "not only is Huawei closing in on Ericsson in terms of worldwide revenues (US\$28.1 billion and US\$28.4 billion respectively in 2010), but Ericsson also saw a steady decline in the volume of sales it generates in sub-Saharan Africa in 2010". Improving technical capacities, low production costs, access to state funding sources and state political support provide Chinese telecom companies with a competitive advantage not available to independent telecom companies.

\section{The two Chinese giant telecom companies (ZTE and Huawei) play an important role in the expansion of Chinese investments abroad and in China's political economy strategy overseas.}

In order to stay competitive in the African telecom market, Chinese companies have developed specific strategies. While investing in Africa, Huawei and ZTE are more focused on customers' needs and requirements. Customer-oriented strategy is the main element of both companies' success in Africa. A better understanding of local population's needs and rapid responsiveness to satisfy such needs, competitive prices, intra-governmental relations and partnership with local telecom operators help Chinese telecom companies in Africa to win trust and reliability among African customers. Pricing strategy remains important for Chinese telecom companies in Africa. Their foreign counterparts have already complained about low Chinese prices for bidding (European Metalworkers' Federation, 2011). According to Wilson Yang, Huawei's former head of operations in West Africa mentioned in a University of Pennsylvania Wharton school case study regarding the company that Huawei manages to achieve tremendous margins pricing itself only 5 to $15 \%$ lower than its international competitors (Chang et al., 2009). On the other hand, ZTE prices 30 to $40 \%$ below European competitors. Rapid responsiveness of the personnel and high customer service are also key elements in Chinese telecom companies' strategies to operate in Africa. ZTE and Huawei always operate with their local telecom partners to establish and control if the base stations placed in rural areas satisfy local populations' needs. After providing customers with telecom network equipment, Huawei and ZTE offer long term maintenance services to ensure the reliable operation of local networks (Yan Weijuan, 2011). 


\section{No shying away from troublesome environments...}

Besides, Chinese telecom companies draw political advantage, economic advantage and political diplomacy while operating in Africa. According to Alden and Davies (2006), based on the concept of "non-interference" in domestic affairs of any state, China is willing to invest in African states regardless of their international standing. In the case of Chinese telecom MNCs, they operate in remote and rural areas in Africa which are sometimes difficult to access due to bad road infrastructure, unreliable and even dangerous to invest in, by building telecom network equipment and base stations to allow local people the benefit of wide network coverage contrary to their western competitors. Economically, the low cost of product development, taking into account R\&D, manufacturing, distribution and sales have allowed ZTE and Huawei to win more markets than their competitors. For instance, Huawei deserves more credit in Africa by not elevating its customer service to a high priority but also considering its pricing strategy in the continent. Chinese telecom companies are able to transfer savings in labour and other resources to low price and use it as leverage in emerging markets like Africa. Low cost bidding has always been a non-negligible aspect in Chinese companies' strategy.

\section{Whina's engagement in Africa's telecom industry has been substantial if we consider the improvement and the growth noticed in the ICT sector across the continent in recent years.}

\section{...- with a little diplomatic help}

Diplomatically, not only telecom companies but also Chinese MNC's are strongly backed in their overseas operations by Beijing's central government. The diplomatic attention paid to African countries by the Chinese government helps to support big projects and development assistance and constitutes an important feature for Chinese telecom companies bidding process. Chinese telecom companies develop political capital in Africa. Huawei and ZTE have not only political ties with China's government but also with host countries' government. When Chinese government leaders visit other developing countries, they are often accompanied by the senior management team of Huawei and ZTE (Fang Lee Cooke, 2011; p.12). Both companies take opportunities during these visits to build political and diplomatic relationships with host countries' policymakers in order to gain influence and reliability and have more important business operations. Public diplomacy in Sino-African relations has become essential in order to rebuild traditional mutual relations and trust.

\section{Conclusion}

China's engagement in Africa's telecom industry has been substantial if we consider the improvement and the growth noticed in the ICT sector across the continent during recent years. By leveraging their expertise and experience in their home and overseas markets, Chinese telecom companies contribute to bridge the digital divide and offer people the chance to join the information and communication era despite their location.

In recent years, China's outward FDI pattern in Africa has shifted from heavy industries to services (telecommunication, banking, finance; etc.). Chinese telecom companies in Africa and their contribution to the improvement of the continent's 
telecom industry is obvious. This new trend of investment in services has probably been driven by China's inward FDI. In China itself, the change from an export-driven to a consumption-driven economy which was initiated by Chinese policymakers in order to avoid the country's economy fully relying on exports has attracted investments in the services sector. ${ }^{1}$

China's investment in Africa's services sector remains important. However, such increased presence in different sectors, mainly in the African telecom industry, has already brought difficulties. The competition from Chinese telecom companies to win tenders has already been denounced by African telecom providers and vendors. Although China's investment in the continent is diversifying, attention should be paid not to exclusively involve Chinese companies in sensitive services sectors. In China itself, although foreign investments in services have been welcomed by the government, sectors such as insurance and consumer banking still remain closed to foreign investors and entirely controlled by Chinese.

It is important to mention that Chinese investments in the telecom sector in Africa came with preferential loans to governments in order to acquire Chinese telecom equipment and infrastructure. The Chinese financiers provided African governments with loans in order to only buy equipment from Chinese telecom companies so they could develop their telecom equipment and services. Also called vendor-guaranteed loans, such loans were offered directly to Chinese telecom companies which already benefited from credit lines. Even if Huawei and ZTE investments in Africa have been welcomed by African governments, problems arise with the presence of both companies in the continent's telecoms sector. In Kenya for instance, contracts between local telecom operators and Chinese companies have been cancelled because of delays in equipment- and infrastructure supply. Besides, telecom investors in African countries mention that Chinese telecom companies have access to markets by using intra-governmental relations between China and Africa. Chinese telecom MNC's should show less suspicion about their activities in Africa and also allow policymakers, organisations and academics to better engage with them, as well as consider better interactions with the public and media through their public relations department. By doing so, they will help reduce the perception of a lack of transparency that surrounds their engagement in Africa, which is not always a positive outcome. Clearly, more transparency is also needed in allocating tenders to telecom companies operating in Africa.

\section{End Notes}

${ }^{1}$ The retail business has become very important for foreign investors in China's cities. For instance, global clothing brands such as H\&M, C\&A, GAP, ZARA, UNIQLO; etc. have opened stores in cities like Shanghai, Beijing, Shenzhen, Guangzhou, Wuhan to target consumers whose purchasing power is increasing.

\section{References}

Alden, C. and Davies, M. (2006). Chinese Multinational Corporations in Africa. Africa Institute of South Africa, Issue 3-4, p.1-11

Beebe, A., Hew, C., Feng, Y.Q. and Shi, D.L. (2006). Going global: Prospects and 
Challenges for Chinese companies on the world stage. IBM business consulting services

Berg, S.V. and Hamilton, J. (2001). "Institutions and Telecommunications Performance in Africa: Stability, Governance and Incentives" in Private Initiatives in Infrastructure: Priorities, Incentives and Performance. E. Elgar Publishing.

Bonaglia, F., Goldstein, A. and Mathews, J. (2007). Accelerated Internationalisation by Emerging Multinationals: The case of White Goods Sector. Munich Personal RePEc Archive Paper $\mathrm{N}^{0}$ 1485, November 7

Buckley, P.J, Clegg, L.J., Cross, A.R., Liu, X., Voss, H. and Zheng, P. (2007).”The determinants of Chinese outward foreign direct investment", Journal of Business Studies (2007) 38, 499-518

Brown, P.J. (2009). "China's mobile phone firms help Africa go mobile". China Business-Asia Times online.

http://www.atimes.com/atimes/China_Business/KK18Cb01.html [accessed on December $5^{\text {th }} 2011$ ]

Chang, C.; Cheng, A.; Kim, S.; Kunh-Osius, J.; Reyes, J. and Turgel, D. (2009). "Huawei technologies: A Chinese Trail Blazer in Africa". Knowledge@Wharton Strategic Management Article, Wharton University

Cooke, F.L (2011). "The globalization of Chinese telecom corporations: strategy, challenges and Human Resources Implications for the MNCs and host countries", The International Journal of Human Resource Management, 2011 p.1-21

Dumbaugh, K. (2008). "China's foreign policy: What does it mean for U.S. global interests?", CRS Report for Congress, July 18, 2008

European Metalworkers Federation (2011). "Fair trade in the telecoms industry", June 2011 [accessed on December $12^{\text {th }} 2011$ ]

Executive Research Associates (2009). "China in Africa: A strategic overview, China's telecommunication footprint in Africa". ERA October 2009, p.50-67

$\mathrm{Gu}$, J. (2009). "China's private enterprises in Africa and the implications for African development", European Journal of Development Research 21, 570-587, September 2009

Li, C. (2006). "China's Telecom industry on the move: Domestic competition, Global Ambition and Leadership Transition", China Leadership Monitor N ${ }^{0} 19$, October 24

Sagalbayeva, R. (2011). "Are Chinese vendors entrenching themselves in Africa?" Analysys Mason, October 24

Salidjanova, N. (2011). Going Out: An Overview of China's Outward Foreign Direct Investment, U.S.-China Economic and Security Review Commission Research Report, 30 March

Shenkar, O. and Luo, Y. (2004). International Business. New York: John Wiley \& Sons, Inc

Xinhua China Economic Information (2006). "Chinese companies backed to go global", March 5

Yan, W. (2011). "Huawei repays its African Community", China Today, vol.60, N ${ }^{0} 10$, October, p.26-28 
Dr Daouda Cissé is a research fellow at the Centre for Chinese Studies. He completed his Master's Degree in 'Foreign Languages Applied to Business and International Trade' at Gaston Berger University in Saint-Louis, Senegal. In 2006, he was awarded a scholarship to study Chinese language and start his PhD programme in International Trade in China the following year. In December 2010, he finished his $\mathrm{PhD}$ thesis on 'Influence of Globalization on Trade: the case of China about imports and exports with African countries'.

After his stay in China and his PhD thesis, his research interests are: China-Africa trade relations, China-Africa economic cooperation. 